\title{
What is the Sarabiyyah?
}

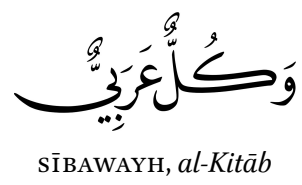

\subsection{Introduction}

In the Western scholarly tradition, it has become customary to consider the language of the Quran to be identical with the language of poetry and the one that established the standard of Classical Arabic, e.g.

The Qurānic language, though virtually identical with the language of pre-Islamic poetry, has a typically religious flavour, manifesting itself in the peculiarities of style and language that must have been absent in other registers.

VERSTEEGH 2014, 65

[T] he Koran established an unchanging norm for the Arabic language

THACKSTON 1994, xii

Apparently independently, H. Fleisch, R. Blachère and C. Rabin arrived in the forties at the conclusion that the language of the Koran, far from being pure Meccan either subsequently revised ... or slightly adapted to the poetic idiom, was none other than the poetic koine.

C. RABIN 1955,24

"At this stage ... it seems safe to say that the Qur'ān was revealed and first uttered in a linguistic form that was, if not identical with the language of poetry, close enough to it to be distinguished rather sharply from the spoken dialects ...

ZWETTLER 1978, 101 
Despite the overabundance of statements of this sort, it remains surprisingly underdefined what the linguistic features of this language are and how we can see what "Classical Arabic" means in these contexts. Even less defined is any concrete evidence that the language of the Quran and poetry are virtually identical despite a near ubiquitous consensus on this point.

Classical Arabic is generally defined by its corpus, rather than through a linguistic definition. The most explicit definition of this corpus that constitutes a single standard form of Classical Arabic was probably formulated by Rabin (1955) "the beginnings of Classical Arabic", who defines Classical Arabic by its traditional corpus, which to him consists of four sources: 1. preIslamic and early Islamic poetry, 2. The Quran, 3. The Hadiths and 4. The first century papyri and letters handed down in history works. All but the last of these sources are still considered today to be part of the corpus of the Sarabiyyah. This is closely in line with what the Arab grammarians themselves felt was material necessary to comment upon for the Sarabiyyah. If we look at what the Arab grammarians, and specifically Sibawayh, the earliest of these whose work we have in writing, consider to be part of the corpus worth commenting upon, we find that they agree to a large extent with the definition of Rabin: Poetry, the Quran and Hadiths play a central role in the linguistic evidence proffered by the grammarians, albeit often to highlight unusual practices.

However, we will argue in this chapter that Classical Arabic is not obviously identical to the "poetic koiné", nor the basis for all descriptions of the language. Instead, it is rather the outcome of a long negotiation of what "proper Arabic" actually is. The early grammarians only mark the start of this negotiation, and it takes centuries for any clear linguistic standard to develop. While many authors consider Sībawayh the first person to codify and standardize Classical Arabic, he does nothing of the sort.

Central in Sībawayh's work, but also what later grammarians focus on, is what "they" say. This elusive "they" is understood, for example by Carter (2004, 39 ), to refer to the natural speech of the Bedouin, but this inference does not seem to be based on the actual statements of Sïbawayh himself. As Webb (2017, 302 ff.) has shown, whenever Sībawayh explicitly assigns a name to the language of "them", it is generally the "speech of the Arabs" (kaläm al-\{arab) that gets mentioned while "bedouin" (?airäb) are only rarely—and, in such cases often negatively — mentioned. Other contemporary grammarians like al-Farrā? (d. 209/824) are much more liberal in assigning tribal association with certain linguistic features found in the Sarabiyyah, but there too, little indication is given that it is specifically the Arabic of the Bedouins that plays a central role. Rather, the main source of the proper use of the Sarabiyyah is by definition a 
prescriptive one; it is the Arabic of "those whose Arabic can be relied upon" (man yūtaqu bi-\{arabiyyati-hī) (Carter 2004, 41).

The modern orientalist tradition has mostly been satisfied in following this prescriptive definition of the Sarabiyyah, but follow this up with an (usually implicit) assumption that what the Arab grammarians considered the Sarabiyyah is more-or-less identical to what modern textbooks such as Wright and Fischer call Classical Arabic. The Classical Arabic as we find it in our textbooks is a fairly homogeneous linguistic unit, with little to no morphological, phonetic or syntactic variation. This, however, is not at all what we find in the earliest descriptions of the farabiyyah, which are absolutely bristling with linguistic variation. Subsequently the identification of the Sarabiyyah as Classical Arabic with strict norms and little variation all exemplified by the disparate corpora such as the speech of "them", the language of poetry, Quran, and hadiths are all lumped together with assumed linguistic homogeneity without actually demonstrating it.

The assumed linguistic unity of these disparate corpora has frequently led to the imposition of facts of morphology and phonology that cannot selfevidently be deduced from the corpora they discuss. For example, on discussing the development of a standard orthography of "Classical Arabic", Versteegh $(2014,64)$ says "in the Hijāz the hamzah was probably absent, but in the variety of the language in which the Qur'ann was revealed and the pre-Islamic poems were composed, the hamzah was pronounced". ${ }^{1}$ While one can indeed make a case for (at least part of) the poetic corpus to have had a hamzah, purely on its necessity in the poetic meter, the assumption that this comes part and parcel with the language of the Quran as well, is not demonstrated, nor in fact particularly obvious. Sïbawayh, for example, reports in detail on the possibility of dropping the hamzah. This is not presented as a non-standard usage, but simply one of the options of Arabic, besides full pronunciation (see Sībawayh, III, 541-556). Considering that Quranic orthography indeed has no way to express the hamzah, and our earliest manuscripts make no use of orthographic means to represent it at all, how can we be so sure it was there? Even if we accept that the Quran was composed in the Sarabiyyah, if the Sarabiyyah is the language described and standardized by the grammarians it is still completely possible that the composition was entirely without hamzah. As we will see, especially in chapter 3, many of the canonical readings today still lack hamzah in many places where the later Classical Arabic would have it.

1 For other quotes of scholars assuming that hamzah must have been the norm in the farabiyyah see also the previous chapter. 
These examples are not just isolated cases, as we will see in this chapter where we will explore the descriptions of the early Arabic grammarians, they allowed for much more variation than the strict norms of Classical Arabic, and no homogeneous standard can be recovered from these works. When one looks closer, we find that the traditional corpora of the Sarabiyyah are noticeably different from one-another, and even within these individual corpora there is significant diversity. Just because they all fall under the aegis of the Sarabiyyah that is the forms of Arabic the Arab grammarians felt the need to comment upon-does not mean they show no systematic and categorical distinct groups from a linguistic perspective.

With recent advances in the study of pre-Islamic and early Islamic Arabic it has now become clear that the Arabic the grammarians saw fit to comment upon is a highly selective subset of forms of Arabic that were around. Exclusively taking that which the grammarians saw fit to comment upon as "Arabic", ignores a vast amount of linguistic variation that existed in the PreIslamic and early Islamic period. As Al-Jallad (2015; 2017a; 2018a) has shown, many other varieties, which are on linguistic grounds evidently Arabic, fall completely outside of the purview of the Arab grammarians. Already in the Pre-Islamic period we find varieties of Arabic that lack the full system of case vowels and nunation, and there is no doubt that such varieties existed in the times the early grammarians were active. Yet, these go completely unmentioned.

Because of this, we now have good reason to doubt the idea that all of Arabic formed a single homogeneous linguistic unit. Moreover, the ambiguities inherent to the Arabic script give a false sense of homogeneity in the "Classical corpora". Little to no skepticism is applied to the vocalizations and interpretations of the originally defective writing of Arabic, even though such disambiguation only appears centuries after the times that these corpora were composed. This is rather surprising as, for example, Rabin $(1955,21)$ seemed to be well aware of the fact that there was a strong classicizing trend towards even the poetic corpus, which, due to its strict meter, is probably somewhat less susceptible to later classicization than, say, the hadiths or the Quran.

Just because the Arab grammarians considered all of the sources mentioned before to be one and the same Sarabiyyah does not mean that they do not show categorical difference from a modern linguistic perspective. The linguistic unity sought by the grammarians should probably be seen more as a sociolinguistic construct than a claim of similarity on a purely (historical) linguistic grounds. The language, no matter what the corpus, needs to be studied independently, and its linguistic features need to be mapped out. Only when it can be shown that the differences in phonology and morphology can be attributed 
purely to stylistic differences, does it seem warranted to call these languages "essentially the same language".

As the Quran was evidently one of the most important works of Arabic literature, grammarians have always felt the need to comment on the language of the Quran and its reading traditions. The Quran, and to some extent its reading traditions, therefore naturally feed into the definition of Classical Arabic - that which the grammarians felt the need to comment upon-but this does not necessarily prove that the language of the Quran and the language of the poetry are identical; it only means that the grammarians discussed both within the same grammatical endeavour. Of course, despite possible differences, clearly the linguistic variation was not so large that describing them together was altogether futile, but considering their scope and considerable tolerance towards linguistic variation, it seems very possible that there are appreciable differences present that set these corpora apart.

\subsection{The Linguistic Variation in the Sarabiyyah}

In the previous section, I argued that the Sarabiyyah (as well as Classical Arabic) is an ill-defined term from a linguistic perspective. It is a language that comes from different sources, all treated by the grammarians as belonging to one single corpus of language. Modern scholars have often accepted the identity of these sources as being all from a single language either called Classical Arabic or "the poetic koiné" which I will call here simply the Sarabiyyah (reserving Classical Arabic for the strict standard that emerged later).

This is problematic on a linguistic level. We do not want to take for granted that these languages are identical, we want to be able to test this hypothesis. It is not a given that any two poems are linguistically homogeneous, nor is it clear that the language of any two hadiths is exactly the same. Far from presenting a clear homogeneous linguistic unit, the Arab grammarians record a vast amount of linguistic variation within their grammars. A large amount of this morphological and phonological variation described by the grammarians falls completely outside of the standard Classical Arabic as it is described, for example, by Thackston (1994), Fischer (2002) or Wright (1896).

Many authors, implicitly or explicitly, assume that the Classical Arabic is in fact what the Arab grammarians describe, with some dialectal forms being described parenthetically on the side. For example Classical Arabic seems to be what Rabin has in mind when he speaks of "Literary Arabic", which he considers the "the standardized form [of Classical Arabic], which was used as the international language in the Abbasid empire" (C. Rabin 1955, 3). Even a cursory 
look at early Abbasid linguistic treaties such as Sībawayh's al-Kitāb or al-Farrā?'s Luġāt al-Quriān reveals a vast number of linguistic variants, options and possibilities which are often mutually exclusive. These do not in any way give the impression that there is a single literary standard. They certainly do not suggest that what eventually becomes Classical Arabic is the default and standard form of the language at this time.

The following section will discuss a variety of cases where the grammarians describe morphological or phonological variation that goes beyond the norms of Classical Arabic. Here we will see that, while occasionally some degree of ranking of forms is given, the preferred form is not always what has become the textbook norm, and very often no explicit judgement is given of which form is better.

I will primarily draw on the two earliest grammatical works on the Arabic language available to us, those of Sïbawayh (d. 18o/796) and al-Farrā? (d. 209/ 824). While Sïbawayh often describes an astounding amount of morphological and phonological variation, he is less judicious about explicitly assigning it to certain dialects of Arabic. In his Luġāt al-Qur?ān, al-Farrā? is much more cursory in his descriptions, but gives more detailed information as to how certain variation is considered to map onto the different dialects. Occasionally we find that these two early grammarians disagree, which in itself is already interesting: two Arab grammarians sometimes describe linguistic facts that are mutually exclusive, and unresolvable. While such occurrences are rare, we will encounter one such disagreement in the discussion of Pimälah (see $§$ 2.2.2.2). In such cases I will also draw on some later grammatical works such as al-Mubarrad (d. 285/898) and al-Paxfaš (d. 215/830), to give a sense of where the consensus may have developed after the disagreement in this early period.

\subsubsection{The Third Person Pronominal Suffixes}

Sïbawayh devotes two subsequent chapters to the morphological allomorphy that is found in the masculine singular and plural pronominal suffixes. He first devotes a chapter to the length of the final syllable of the pronominal suffixes -hu and -hum (and -kum, -tum, Pantum) (Sỉbawayh, IV, 189) and then on the vowel harmony that occurs in these two suffixes (Sïbawayh, IV, 195).

According to Sibawayh, the pronominal suffix $-h u / i$ is short when it follows a long vowel $(\bar{a}, \bar{l}, \bar{u})$ or a diphthong $(a y, a w)$. In all other cases the vowel, in principle, is long. Hence, after any short vowel $(a, i, u)$ or consonant the suffix is long $-h \bar{u} / \bar{\imath}$. This is an interesting deviation from Classical Arabic as it is presented, for example in Fischer (2002, §268.3), who holds that after closed syllables the suffix should be short, i.e. min-hu whereas Sïbawayh argues for 
min-hü. He says that only "some Arabs" would use the form min-hu, but to him the full pronunciation is better (al-Pitmāmu ?ağwad). In other words, what is now the normative form in Classical Arabic, seems to have only been a minority form in Sībawayh's view, and moreover a form he explicitly values lower than the other form he describes.

Interesting to our discussion here is that after the discussion of the shortened and lengthened forms, Sibawayh tells us that the Quranic quotes wanazzalnā-hu tanzïlan (Q17:106), Pin tahmil Salay-hi yalhat (Q7:176), wa-šarawhu bi-țamanin baxsin (Q12:20) and xudū-hu fa-gullu- $h u(\mathrm{Q} 69: 30)$ are the "better of the two readings". He does not elaborate on what the other reading would be, but as all of these forms have - $h u$ preceded by long vowels and diphthongs, it is obvious that the lengthening of the pronoun is meant in this context $(-h \bar{u},-h \bar{\imath})$. This is the reading of Ibn Katiir, the Meccan reader of the canonical seven (Ibn al-Ǧazarī, § 1212). While Sỉbawayh values these lengthened forms less than the shortened ones, he explicitly tells us that the lengthening is Arabic (al-Pitmāmu Sarabiyy). Being 'less good' or 'less common', therefore, does not disqualify a form from being Sarabiyy.

While al-Farrā? does not discuss the length of the pronoun $-h u / \bar{u}$ after a consonant in Luḡàt al-Quriān, he does address this in his MaSāni al-Qur?ān (I, 224f.), where he says that "they" pronounce such forms with short vowels, giving daS-hu yadhabu, min-hu, $\{a n-h u$ as examples, and announces that "they" hardly ever say [wa-lā yakādūna yaqūlūna] min-hū, ৎan-hū. Al-Farrā? here therefore has the opposite opinion of Sïbawayh.

Al-Paxfaš (Maৎānī, 27), direct student of Sībawayh, follows his teacher in preferring min-hu while expressing a much more normatively negative opinion of min-hu saying it is not good in Arabic [wa-hā $\underline{d} \bar{a}$ laysa bi-ğayyidin fì lSarabiyyah]. Whereas al-Mubarrad (al-muqtadab, I, 401) explicitly endorses the short form min-hu. It therefore does not seem that the competing opinions on what was the proper way of treating such cases was resolved in the generations after Sībawayh.

Sïbawayh informs us that speakers have a choice for the plural pronoun hum/-him, they can either choose to keep it short, or use lengthened forms -humū and the harmonized variant -himi pronoun. This lengthening also involves other masculine plural pronominal elements such as ?antumu,$-t u m \bar{u}$, -kumū and the independent pronoun humū. Al-Farrā? (Luġät, 33) agrees with the optionality of this feature, saying, "the Arabs are united in [both options:] not placing a vowel after the $m$, or placing an $u$ after it. In their speech it is: minhum or minhumū; falaykum or Salaykumū; kuntum or kuntumū. We do not know it as being exclusive to anyone (to have) one of the two linguistic practices (lugatayn). All of them say it in both articulations (al-qawlayn)." 
As for the harmonized form, Sibawayh tells us that 'some of them' use -himu instead of -himi. Here once again, we find a conflict with Classical Arabic; While Fischer (2002, § 268.4) informs us that lengthened forms like -humu and -himū, are used in poetry, he makes no mention of the existence of a pronominal-himi, and this form seems to have largely fallen out of use in normative Classical Arabic, except when end rhyme in poetry requires it. Moreover, note that the forms presented by Sỉbawayh and al-Farrā? in no way seem to imply that they are to be used in poetry only, or even primarily. This is different, for example with the shortened pronominal suffix - $h u /-h i$ after short vowels, which Sībawayh explicitly only allows as a poetic license.

In the second of the two chapters Sibawayh addresses the vowel harmony, which shows that the allomorphs $-h \bar{\imath},-h i,-h i m$ and $-h i m \bar{\imath}$ (and -him $\bar{u}$ ) are triggered by a preceding $i$ or $y$. While the vowel harmony is the general form that Sibawayh presents first, he also informs the reader that the people of the Hijaz

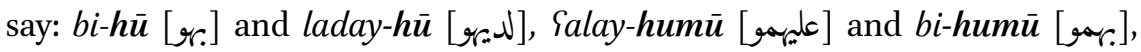
showing that the people of the Hijaz both lacked vocalic length disharmony and vowel harmony. He adds that the Hijazis recite the Quran $f a-x a s a f n a \bar{b} b i-$

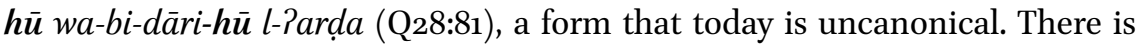
no obvious expression of derision for these non-harmonizing forms. Al-Farrā? (Lug $\bar{a} t, 10-11$ ) likewise attributes the lack of vowel harmony to the Qurayš, the people of the Hijaz in general, and the eloquent people from Yemen, whereas the presence of vowel harmony is attributed to the Pasad and Qays and Tamim. He adds that Kinānah and SaYd b. Bakr normally apply vowel harmony to the plural pronoun, but before a two consonant cluster this vowel harmony is removed (e.g. Salayhumu l-qawla), explicitly mentioning that this is the practice al-Kisā?i adopts and that it is the most eloquent of linguistic practices. The forms al-Farrā? cites for the Hijaz do not have the final long vowels on the plural pronoun forms as Sibawayh mentions, which should probably be understood to mean that at least according to al-Farrā? the long forms of the plural pronouns are optional also in Hijazi Arabic, something in line with the optionality of length as a general feature.

We should take the lack of derision as a serious indication that the Hijazi norm is simply considered acceptable. This is clear from the fact that Sỉbawayh does not avoid derision elsewhere when it comes to pronominal harmony. He considers the min-him used by the eastern tribe of Rabī tic practice [lugiah radī?ah] and the ?ahlāmi-kim and bi-kim used by one of the branches of Rabīiah, Bakr b. Wā?il, to be extremely vile [radī? ǧiddan]. Clearly the Hijazi forms fell within the purview of what Sibawayh considered eloquent and correct Arabic and he thought of a too liberal use of vowel harmony to be more problematic than its absence. 
A final note is given on the shortening of the pronominal suffix vowels before consonant clusters; here Sïbawayh seems to allow both -himu or -himi as the harmonized form.

Sībawayh and al-Farrā? do not present a clear single norm and accept a variety of different treatments of the pronominal system. The tables below summarize their descriptions (leaving out the things they consider unacceptable). A $\downarrow$ sign marks that a form is explicitly devalued in relation to the basic system, while these are still considered proper and Arabic, while $\uparrow$ marks a form that is explicitly considered better., $\mathrm{F}$ and $\mathrm{S}$ behind the $\downarrow$ and $\uparrow$ signs mark a difference of opinion between al-Farrā? and Sībawayh.

\begin{tabular}{|c|c|c|c|c|c|c|c|}
\hline & \multicolumn{2}{|l|}{ Base } & \multicolumn{2}{|c|}{ Lengthened } & \multicolumn{2}{|c|}{ Classical Arabic } & \multirow{2}{*}{$\begin{array}{l}\text { Hijazi } \\
\text { Base }\end{array}$} \\
\hline & Base & $\mathbf{i}, y_{-}$ & Base & $\mathrm{i}, \mathrm{y}_{-}$ & Base & $\mathbf{i}, y_{-}$ & \\
\hline$\breve{V}_{-}$ & $-h \bar{u}$ & $-h \bar{\imath}$ & $-h \bar{u}$ & $-h \bar{\imath}$ & $-h \bar{u}$ & $-h \bar{\imath}$ & $-h \bar{u}$ \\
\hline $\mathrm{C}_{-}$ & $-h \bar{u}$ & & $-h \bar{u} \downarrow F$ & & $-h u \downarrow S$ & & $-h \bar{u}$ \\
\hline $\bar{V}_{-}$ & $-h u$ & $-h i$ & $-h \bar{u} \downarrow$ & $-h \bar{\imath} \downarrow$ & $-h u$ & $-h i$ & $-h \bar{u}$ \\
\hline
\end{tabular}

Singular pronominal system

\begin{tabular}{|c|c|c|c|c|c|}
\hline & \multicolumn{2}{|l|}{ Base } & \multicolumn{2}{|c|}{ Classical Arabic } & \multirow{2}{*}{$\begin{array}{l}\text { Hijazi } \\
\text { Base }\end{array}$} \\
\hline & Base & $\mathrm{i}, \mathrm{y}_{-}$ & Base & $i, y_{-}$ & \\
\hline Short & -hum & -him & -hum & -him & -hum \\
\hline Long & $-h u m \bar{u}$ & -himī & -humū & -himū & -humū \\
\hline _CC & -humu & -himi, -humu $\uparrow F$ & -humu & -himu & -humu \\
\hline
\end{tabular}

Plural pronominal system

\subsubsection{The Extra Vowels of Early Classical Arabic}

The medieval Arab grammarians, and with them many modern scholars of the Arabic language, conceive of Pimālah as a shifting from an original $\bar{a}$ towards the $\bar{l}$, ending up generally in between the two, i.e. $\bar{e}$. While from a historical linguistic perspective this is true for a part of what the Arab grammarians call Pimālah, it certainly is not true for all of what they collect under this label. Lack of awareness of this has led many a scholar (e.g. Levin 1992) 
to the incorrect conclusion that in terms of the phonology of the vowel system of Classical Arabic from Sībawayh's lifetime onwards, there was a fairly homogeneous system, namely, one that had three long vowels $\bar{a}, \bar{\imath}$ and $\bar{u}$ and three short vowels $a, i, u$. In this interpretation Pimālah would simply be allophonic variation, and belong to the realm of phonetics rather than phonology.

As we will see in this section, this is certainly not the case. Under the rubric of what Sïbawayh calls Pimālah there are clear examples of what in modern phonological theory would be thought of as phonemic distinctions; as such Sībawayh describes forms of Arabic that have a phonemic fourth vowel $\bar{e}$ besides the three base vowels. Some of these distinctions are maintained in the Quranic reading traditions and, moreover, one of these systems corresponds to the fourth long vowel $\bar{e}$ that can be deduced to exist in the language of the QCT on the basis of orthography and Quranic rhyme (Van Putten (2017a), § 3.3.3 and $\S 5.8$. For a useful translation of Sïbawayh's chapters on Pimälah see the translations and analysis of Sara (2007).

Besides this, the early Grammarians also speak of a back vowel in between $\bar{a}$ and $\bar{u}$, that is, $\bar{o}$ (called Palif al-Tafxim by Sībawayh) and even a front rounded vowel $\ddot{u}$ and its long equivalent $\tilde{u}$. None of these variants are presented as incorrect Arabic, and significantly increase the phonological vowel inventory compared to what we might call Classical Arabic.

\subsubsection{1 i-umlaut}

Sïbawayh discusses Pimālah at length, and within this discussion one type of Pimālah, namely the shift of $\bar{a}$ to $\bar{e}$ in the vicinity of $i / \bar{l}$, is most dominant. This shift is blocked whenever there are emphatic or uvular consonants $(s, d$, $t, z, \dot{g}, q, x)$ adjacent to the $\bar{a}$ or following it, but is not blocked if the umlauttriggering $i$ stands between the blocking consonant and a following $\bar{a}$ such as in XiCāC stems where $\mathrm{X}$ is one of these blocking consonants (Sïbawayh 1988, IV, 117-120; 127-136; Sara 2007, 9-16; 56-65; 121-122, 133-134). ${ }^{2}$ The consonant $r$ holds a special position in this Pimālah. It behaves as an emphatic $r$ when followed by $\bar{a}$ or when it is preceded by $\bar{a}$ and not followed by $i$ or $\bar{l}$. As a result, this blocks the Pimālah: rāšid, himārun but not of min himerri-ka. Interestingly, the sequence $\bar{a} r i>\bar{e} r i$ is stronger than blocking emphatic consonants. Thus, one says qêrib 'boat', têrid 'expeller'. Likewise nouns with the shape CaCāC and

2 Close parallels of this type of $i$-umlaut Pimālah are well-attested in many modern Arabic dialects, for example in Christian and Jewish Baghdadi (Blanc 1964, 42). For an in-depth discussion on the parallels of Sỉbawayh's $i$-umlaut Pimālah and what we find attested in the modern dialects see also Levin (1992). 
CuCāC, which normally block Pimālah if the genitive follows, undergo Pimālah when the last root consonant is $r$.

This type of Pimālah seems to have been widespread, as Sïbawayh only tells us that "the people of the Hijaz apply Pimālah to none of these" (Sara 2007, $12 \mathrm{f}$.). $\mathrm{Al}$-Farrā? $($ Lug $\bar{a} t, 22)$ does not comment in great detail on this type of Pimālah, mentioning only al-käfirūna is pronounced as such by the people of the Hijaz while some of the people of Najd among the Tamìm and Qays say al-kéfirüna. This simple $i$-umlaut does not create a distinction between a phonemic $\bar{a}$ and $\bar{e}$, but should rather be considered a purely allophonic alternation. The table below provides an overview of examples cited by Sībawayh.

\begin{tabular}{|c|c|c|}
\hline Pattern & $\begin{array}{l}\text { Non-emphatic/Uvular } \\
\text { environment }\end{array}$ & $\begin{array}{l}\text { Emphatic/Uvular } \\
\text { environment }\end{array}$ \\
\hline CāCiC & 乌ēbid 'worshipper' & ḍ̂min 'guarantor' \\
\hline $\mathrm{CaCāCiC}$ & masēǧid 'mosques' & maSāliq 'pluck of animals' \\
\hline $\mathrm{CaCāCīC}$ & mafètīh 'keys' & manāfix́x 'bellows' \\
\hline CiCāC & kilēb 'dogs' & No example, but blocked \\
\hline CiCCāC & sirbēl 'shirt' & No example, but blocked \\
\hline
\end{tabular}

This type of Pimālah is no longer common in Classical Arabic pronunciation today. In fact, it receives no mention at all in many modern grammatical works, such as Fischer (2002), or it is explained as a behaviour of "later times" (Wright 1896, §6c) despite the earliest grammarian describing it, clearly marking it as part of the Sarabiyyah. It is described in great detail by Sïbawayh, and it is not dismissed as 'wrong' or 'less regular'. In fact, Sỉbawayh does not express any negative judgement of such forms at all. He only tells us that the people of the Hijaz do not do it. We must therefore conclude that using this type of pronunciation was considered acceptable and part of the linguistic variation present in the Sarabiyyah that Sỉbawayh sought to describe. In fact, about a century later the Basran grammarian al-Mubarrad (d. 285/898) explicitly evaluates the use of Pimālah as better (Muqtadab III, 42), showing that this is not just a nonstandard feature that happened to end up in grammarian descriptions, but rather is part of the variation that can be explicitly endorsed.

2.2.2.2 III-y Pimālah

The $i$-umlaut Pimālah as discussed above can be plausibly thought of as the allophonic realization of $\bar{a}$, as it is predictable when it does and does not occur. 
However, there are several other forms of Pimälah that certainly cannot be considered allophonic, but must describe a true phonemic fourth long vowel $\bar{e}$ that existed beside $\bar{a}, \bar{\imath}$ and $\bar{u}$. Sỉbawayh says that this type of III-y Pimālah is uncommon both among the Tamim and others (Sïbawayh, IV, 120; Sara 2007, 20 f.), while al-Farrā? (Lugia t, 21f.) says that many of the people of Najd apply it. These statements appear to be contradictory, and their respective descriptions also differ somewhat.

Sïbawayh points out that nouns that have a root final consonant $w$ do not undergo Pimālah. Hence you get قفا qaā 'back', عصا Sașa 'stick' القنا al-qanā 'the aquiline nose' and القطا al-qața 'the sand grouse'. This is different from those with root-final $y \bar{a}$ ?, which do undergo Pimālah (no examples given, but e.g. al-hawē 'the affection' and المتى al-fatē 'the youth'). Feminine nouns that have the suffix $-\bar{a}$ (spelled with $y \bar{a}$ ?) are likewise treated as nouns that have a root final $y \bar{a} r$ : معزى $m i \oint_{z \bar{e}}$ 'nanny goat' and حبلى hublē 'pregnant'. Derived forms that end in $-\bar{a}$ (spelled with $y \bar{a} ?$ ) likewise always undergo Pimālah, as derived stems shift their root final consonant from $w$ to $y$ (as can be seen in the dual, such as ?a Stayā 'they (dual) gave' but Sațawāni 'two gifts'). Hence, we find muSțē 'gifted'.

Where nouns (for those who apply this type of Pimälah) have a distinction between root final $w \bar{a} w$ and root final $y \bar{a} ?$ stems, Sibawayh says this is not the case for verbs. Hence $\mid \dot{\xi} \dot{g} a z \bar{e}$ 'he raided', صف șafēe 'it became clear' and د 'he called', just like e.g. رمى ramēe 'he threw' and بنى banē 'he built'.

He explicitly adds that this final weak Pima alah is not blocked by emphatic consonants, thus you have muStẹe 'gifted' and saqe 'he watered' (Sïbawayh, IV, 132; Sara 2007, 66 f.), clearly indicating that we are not dealing with an allophonic shift from $\bar{a}$ to $\bar{e}$ similar to the $i$-umlaut Pimālah discussed in the previous section. Moreover, there are places where the occurrence of $\bar{a}$ and $\bar{e}$ cannot be reconstructed from surface forms like *al-fatā and *al-\{așā, so we must conclude that for the variety that Sïbawayh describes to have this type of Pimālah we are dealing with a phonemic distinction between $\bar{a}$ and $\bar{e}$. Comparative Semitic evidence, most notably the epigraphic old Arabic dialect of the Safaitic inscriptional corpus and Classical Ethiopic show that the long vowel distinction between III- $w$ and III- $y$ stems is the outcome of two etymologically different sequences (see van Putten 2017a for a discussion). Thus, the contrastive vowels of al-fatē and al-Sașā come from *al-fatayu and *al-Sașawu respectively.

While this etymological distinction is retained in the noun, according to Sîbawayh, it is lost in the verb. This is rather surprising, as we would expect that, as with the noun, original *banay $a$ and "da ${ }^{*} a w a$ would yield bane and $d a \varphi \bar{a}$, something that is also reflected in Classical Arabic orthography. Sībawayh seems to 
be quite alone among the early grammarians in maintaining that the verb must lack this distinction. Al-Farrā? (Luġāt, 21) tells us that "many among the people of the Najd apply Pimálah [lit.: place an $i$-vowel] when they say qadè, ramēe and sawwe, and they place an $a$ vowel on roots with $w \bar{a} w$ as the third root consonant, for example in wa-Pidā xalā bậ̣u-hum (Q2:76) and $m \bar{a} z a k \bar{a}\left(\mathrm{Q}_{24: 21)}\right.$, and what is like it." Al-Mubarrad (III, 44) explicitly states that Pimālah is ugly

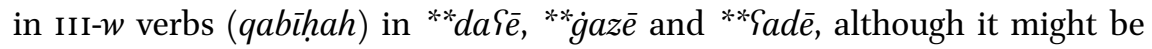
barely acceptable (qadyağüzu \{alā bu§d), while for III-y verbs it is considered good (hasanah) be it a noun, verb, or adjective. Sībawayh's student, al-Paxfaš alPawșat (d. 215/83o) endorses both contradictory statements, he says that many of the Arabs (katîran mina l-Sarab; MaSānī, 41) did not apply Pimālah to forms to III-w verbs, while many (other) people (nāsun kațīr; MaSānī, 42) did apply it to verbs with wāw.

There is yet another system of final weak Pimālah that Sïbawayh discusses as somewhat of an afterthought, but from a modern dialectological perspective highly relevant. As Levin ("Sībawayh's 'Imāla", 87) points out, besides the system where III- $y$ and III- $w$ verbs are merged towards having Pimälah while nouns remain distinct, there also seem to be dialects where the III- $y / w$ verb merged towards not having Pimälah and only has Pimälah on the nouns with the feminine ending $-\bar{e} /-\bar{a}$, as examples Sībawayh (IV, 126) cites speakers who say ramā 'he threw' but hublēe 'pregnant' mi $\bar{z} \bar{e}$ ' 'goat'. As Levin points out, this corresponds with the Pimālah as we find it in the Mesopotamian Qəltu dialects which have hable 'pregnant', ?aSme 'blind' but ramā 'he threw', retaining the ancient vowel contrast.

\begin{tabular}{llllll}
\hline & $\begin{array}{l}\text { Base } \\
\text { Síbawayh }\end{array}$ & Qoltu-like & al-Farrā? & al-Mubarrad & $\begin{array}{l}\text { No III-y/w } \\
\text { Pimālah }\end{array}$ \\
\hline III-y verb & $-\bar{e}$ & $-\bar{a}$ & $-\bar{e}$ & $-\bar{e}$ & $-\bar{a}$ \\
III-w verb & $-\bar{e}$ & $-\bar{a}$ & $-\bar{a}$ & $-\bar{a} \uparrow,-\bar{e} \downarrow$ & $-\bar{a}$ \\
III- $y$ noun & $-\bar{e}$ & $-\bar{e}$ & $?$ & $-\bar{e}$ & $-\bar{a}$ \\
III-w noun & $-\bar{a}$ & $-\bar{a}$ & $?$ & $-\bar{a}$ & $-\bar{a}$ \\
\hline
\end{tabular}

While Sībawayh reports final weak Pimālah to be a minority pronunciation, it is in no way judged to be incorrect or less eloquent. Al-Farrā? does express a normative preference, but infavour of distinguishing $\bar{a}$ and $\bar{e}$ saying "the best of that is the case when it is between the strong application of kasr and the strong application of fath, and following this are most of the Arabs and Quranic read- 
ers." ${ }^{3}$ This clearly indicates that normatively it is better to pronounce the III-y verbs with something that is not identical to a pure $\bar{a}$ vowel.

This once again shows that we certainly cannot project back the later norms of Classical Arabic to this period. As far as al-Farrā? is concerned, the normative pronunciation of Arabic is with four separate phonemic long vowels $\bar{a}, \bar{\imath}, \bar{u}$ and $\bar{e}^{4}$

\subsubsection{II-w/y Pimālah}

In his chapter on Pimālah, Sỉbawayh (IV, 120f.) tells us that "they apply Pimālah" to hollow verbs, whose 1sg. form has an $i$ vowel, be they II-w or II-y (e.g. xêfa/xiftu 'to fear', ğểa/ği?tu 'to come'). He also adds that this is a linguistic practice for some of the people of the Hijaz. It seems clear that the "they" he refers to more generally in this section are not the people of the Hijaz, as earlier he tells us that "the people of the Hijazi do not apply Pimālah to all of this" (IV, 118). Further dialectal specification of this type of Pimālah is not given, but alFarrā? (Lug $\bar{a} t, 17)$ adds that it is the practice of the common people of the Najd among the Tamim, Pasad and Qays.

This, once again, cannot be understood as an allophonic alternation between $\bar{a}$ and $\bar{e}$. One cannot predict from the surface form without Pimālah whether it will have $\bar{a}$ or $\bar{e}$, nor is it conditioned by the presence or absence of emphasis. Instead, it represents two outcomes of etymologically distinct forms of the verb, verbs with a medial triphthong ${ }^{*} a W i$ yielding $\bar{e}$ and ${ }^{*} a W u$ (or * $a W a$ ) yielding $\bar{a}$ (where $W$ is a $w$ or $y$ ). That these verbs once had triphthongs in medial position is quite clear from the Old Arabic dialect reflected in the Safaitic inscriptions, where such verbs often remain uncontracted with a consonantal $y$ or $w$ (Al-Jallad 2015, 119). For example, we find byt the spent the night', ' $w d$ 'he returned' and $r w h$ 'he departed at night'. Safaitic does not make use of matres lectionis, and therefore this points to forms like /bayita/, / /awada/ and /rawaha/ respectively. The original triphthongs of these hollow roots are further confirmed by forms like Gə९əz kona < *kawuna, and Suchard (2016) shows that a triphthongal origin can also be reconstructed for Proto-Hebrew. This then retains an archaic contrast that is absent in Classical Arabic. The examples with the hollow root Pimälah as discussed here must be a different

3 Wa-Pahsanu dẹalika Pamrun bayna l-kasri š-šadìdi wa-l-fatḥi š-šadīdi, wa-Salay-hi Taktaru lSarabi wa-l-qurrā?.

4 Considering that his teacher al-Kisāî̄ and subsequently also his teacher Ḥamzah both retain a phonemic distinction between $\bar{e}$ and $\bar{a}$ in III- $y$ and III- $w$ verbs respectively in their Quranic readings (see §3.3.3.3), it is of course not surprising that al-Farrâ? would consider this the better practice. 
outcome from the collapse of these triphthongs, rather than an unmotivated shift from $* \bar{a}>\bar{e}$.

Unlike the final weak verbs, where the root consonant determines the outcome of $\bar{e}$ versus $\bar{a}$, for hollow roots, it is the second stem vowel that determines the outcome of this collapse. This much is clear from verbs such as mèta, mittu whose verbal noun mawt leaves little doubt that the root is, in fact, $\sqrt{\mathrm{mwt}}$, and the same can be said for xêfa, xiftu whose verbal noun is xawf beside forms such as șerra, șirtu with a verb noun șayr. This is similar to the Hebrew situation where we find met 'he died' but mawet 'death', which Suchard argues means we must reconstruct * mawita and "mawt with a collapse of *awi in the hollow root to $\bar{e}$. A similar development must be envisioned for forms of Arabic with this type of Pimālah.

Note that this shift does not necessarily take place in varieties that also have an $\bar{a} / \bar{e}$ distinction for the III-w/y verbs. Sïbawayh attributes this II-w/y Pimālah to the poet Kutayyir Sazzah (Sara 2007, 22 f.), an Umayyad poet whom he quoted in the previous section for not having Pimälah for III-w/y verbs. The reverse is also true: the dialect on which the Quranic and classical orthography was based clearly only had $\bar{a}$ for II- $w / y$ verbs, hence the consistent spelling with Palif whereas III- $w / y$ are kept strictly distinct (see $\S 5.8$ ).

While Sïbawayh considers this a rare feature, it is in no way considered bad and is indeed qualified by citing an early Umayyad poet. Al-Farrā? (Lug àt, 17), like with the previous feature, explicitly endorses having this type of contrast, in very similar wording as in the previous section, saying: "the best of that is the case when it is between the excessive application of kasr and the excessive application of fath. Sāșim applies the fath excessively, and Hamzah the kasr excessively."5 As al-Farrā? only mentions Quranic readers here and does not say that most of the Arabs do it this way, this statement should perhaps be interpreted as only being normative for Quranic recitation, rather than for spoken Sarabiyyah. What is clear, however, is that neither Sïbawayh nor al-Farrā? considered this practice as incorrect or not belonging to the Sarabiyyah.

\subsubsection{The Fifth Long Vowel Ō}

While Sibawayh spends very few words on the presence of a backed and rounded counterpart to the mid front vowel $\bar{e}$, that is, a long $\bar{o}$, it is clear from his account that it existed. In a list of sounds that are not basic to the Arabic

5 Wa-Pahsanu dālika Pamrun bayna l-kasri l-mufriți wa-l-fathi l-mufriți, wa-kāna Sāșimunyufrițu fil-fathi, wa-hamzah yufriț l-kasri. 
alphabet but acceptable for the recitation of the Quran and poetry, Sỉbawayh (IV, 432) speaks of an Palif al-tafxim typical of the people of the Hijaz in the words aș-șalōh 'the prayer', az-zakōh 'the alms' and al-hayōh 'the life'. While this has been interpreted by Rabin $(1951,107)$ as a general tendency to pronounce any long $\bar{a}$ as $\bar{o}$ in the Hijaz, that is clearly not what Sībawayh is referring to. ${ }^{6}$ The three words Sibawayh cites are exactly the words that are spelled with a $w \bar{a} w$ in the orthography of the Quranic Consonantal Text,7 i.e. الصلوه ,الزكوه and غدوه gadōh 'morning' and النجوه an-nağōh 'escape'. There are good reasons to think that these were indeed pronounced with an $\bar{o}$ in Quranic Arabic (see Al-Jallad 2017c; van Putten 2017a), and it can hardly be an accident that it is exactly these words that Sībawayh decided to cite. Al-Farrā? (Lugāt, $45 \mathrm{f}$.) is aware of such a pronunciation, and states that it is said that the eloquent ones of the people Yemen pronounce it $a s ̦-s ̦ a l o ̄ h$ and $a z-z a k o ̄ h$, but that he has not heard it himself, this may suggest that this pronunciation was already losing popularity by his lifetime.

This $\bar{o}$ vowel once again does not develop from $\bar{a}$, but rather has a clearly distinct etymological origin (nouns ending in *awat-) (see Al-Jallad 2017c; van Putten 2017a), and should therefore be considered phonemic amongst speakers that have this ?alif al-tafxim. This introduces a fifth long vowel, which, moreover, is explicitly considered acceptable by Sibawayh for the recitation of the Quran. It was clearly part of at least some people's speech whose pronunciation Sỉbawayh respected, and considered this authoritative enough to use it in Quranic recitation.

\subsubsection{The Front Rounded Vowel in Hollow Passives}

The passives of hollow roots are reported by Sibawayh (IV, 342 f.) to come in three different forms: He starts with the Classical Arabic qila/qiltu, but then adds that "some arabs" say xüffa/xüftu, bü̧a/büstu and qüla/qültu, applying

6 This belief seems to stem from generalized and abridged statements of later grammarians. Al-Mubarrad, for example, copies much of the same wording of Sïbawayh considering the sounds that exist in Arabic, but simply mentions the ?alif al-tafxim, while leaving out the words that serve as an example of the ?alif al-tafxim as well as the dialectal origin (AlMubarrad muqtadab, I, 330), this is likewise the case for Ibn al-Sarrāğ (?ușūl, III, 487). This lack of precision in later sources should, of course, not be seen as evidence that Sībawayh was wrong and the general statement should be accepted. Ibn al-Sarrāğ's wording is copied verbatim from Sībawayh's al-Kitāb, but has only been abridged. The removal of the reference to the words and tribal identification are simply part of the abridgement process.

7 The edition of al-Kitāb I consulted spells them with ?alif. 
lip rounding $(f a-y u s ̌ i m m u)^{8}$ and "some arabs" say $x \bar{u} f a / x u f t a, b \bar{u} \uparrow a / b u \uparrow t u$ and qūla/qultu. While Sībawayh does not specify which dialects use which forms, al-Farrā? (Luḡät, 14) does: The people of the Hijaz apply the kasrah: qüla/qiltu; Many of the Qays, Guqayl and the common people of Pasad hint towards the

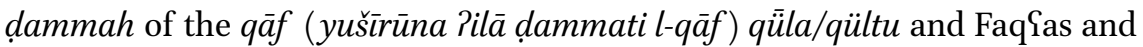
Dubayr (branches of ?asad) say qüla/qultu. No specific preference of one form over the other is expressed. ${ }^{9}$

There is no way to derive at qüla or qūla from qüla historically, and all three reflexes must be seen as different outcomes of the original triphthong *quwila. Rabin $(1951,159)$ provides a plausible scenario for these outcomes. He suggests that all the dialects described by the grammarians first underwent a shift of * $u W i>\bar{u}$. Subsequently in the Hijaz, this $\bar{u}$ shifted to $\bar{\imath}$ retaining the frontness but losing the rounding, whereas Faq Sas and Dubayr shifted it to $\bar{u}$, losing the frontness but retaining the rounding. The central dialects of Qays, Suqayl and the majority of ?asad retained the front rounded vowel. But different explanations of the facts may be envisioned as well. The Hijaz and Qays/Yuqayl/Rasad forms may have been the outcome of separate collapses of the triphthongs. In Classical Arabic only the qüla form has survived, although Fischer (2002, $\S 246.3)$ notes that forms like qūla may occur in poetry.

\subsubsection{Najdi Vowel Harmony}

One of the phenomena that is attributed to a development in the language of the Tamim by Sibawayh (IV, 107-109), is the vowel harmony triggered by a sequence of aGi or aGī, where $\mathrm{G}$ stands for an intervening guttural consonant, $?, h, h, \uparrow, x, \dot{g}$. This affects nouns, adjectives and verbs alike..$^{10}$ Forms he cites are:

Pišmām as lip rounding is clearly explained by Sībawayh (IV, 168-176) in one of the chapters on pause, where it is described as an option for pausing on nouns that end in $-u$.

What Sïbawayh does say, however, is that the qïla/qiltu form is the "origin" (Paṣl). This is a technical term which in Sïbawayh's framework means it is the form from which all forms are derived. But this technical term cannot be understood as meaning the "normative" or "Classical Arabic" form. Taking the term Paṣl as meaning the "normative" form would not result in Classical Arabic. To Sībawayh, for example, unharmonized and long - $h \bar{u}$ and humū, naSima/ba?isa rather than niSma/bi?sa and wa-li-yaktub instead of wa-l-yaktub are all described as the ?aṣl but do not make it into the Classical Arabic norm. As Sïbawayh's approach is not historical, ?așl can of course not be understood as "origin" in the historical linguistic sense either.

10 Many modern dialects, as for example Egyptian Arabic, show the exact opposite distribution: if there is no adjacent guttural the adjective is $\mathrm{CiCī} C$, whereas with a guttural adjacent it is CaCīC, e.g. kibir 'big' but sa ìd 'happy'. In the modern Arabic dialect of Sanaa, however, we find the exact distribution that is described by Sïbawayh (Julien Dufour personal correspondence). 


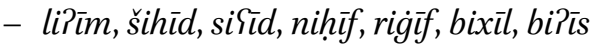

- šihid, liSib, dihik, nigill, wixim, mihik, lihim, wiSik, xiìiz, niSir, fixid

In the speech of the people of the Hijaz, however, this vowel harmony does not take place. Again, both options are mentioned, but no specific preferences are expressed for either form.

Al-Farrā? (Luġăt, 5) discusses this same shift for CaGīC nouns, reporting that Hijazis and ?asad retain the $a$ but that Qays, Tamīm, RabīYah and those that sur-

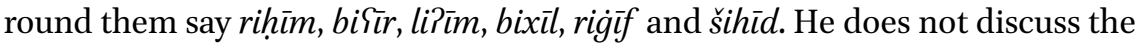
treatment of $\mathrm{CaGiC}$ stems in a systematic way, but comments on several cases where it has clearly taken place. For example, he attributes niSim-ma to Qays and Tamīm, while he attributes naSim-mā to the Hijaz (Luġăt, 41). He mentions that some of the Tamìm say țihirta for tahirța (Lugàtt, 125). He also mentions Tamīmī ar-riḥm for Hijazi ar-rahim (Lugäăt, 128) with Najdi syncope (see next section).$^{11}$ Once again the grammarians present the two forms as coming from different dialects, but no specific preference is expressed for the Sarabiyyah. In Classical Arabic, however, such harmonized forms have disappeared completely.

\subsubsection{Najdi Syncope}

Both Sībawayh (IV, 113-115) and al-Farrā? (Luġāt, 29) report a far-reaching syncope of the high vowels $i$ and $u$ when they are preceded by a light syllable $(\mathrm{Cv})$. $\mathrm{Al}$-Farrâ? reports this for the people of Najd, while Sïbawayh specifies it more and says that it is the linguistic practice of the Bakr b. Wā?il and many people of the Banū Tamīm. Al-Farrā? attributes the full pronunciation to the people of the Hijaz, whereas Sïbawayh does not specify what dialect has the full pronunciation.

Al-Farrā? mentions three categories to which this development applies: first, to the pronouns huwa and hiya when preceded by $w a-, f a-$ and $l a-$; second, to nouns of the shapes $\mathrm{CaCiC}, \mathrm{CaCuC}, \mathrm{CuCuC}, \mathrm{CiCiC}$ and feminine equivalents; third, it applies to the $l i$ - placed before the jussive for orders. While not explicitly mentioned by al-Farrā?, Sībawayh adds that it also applies in $\mathrm{CaCiC}, \mathrm{CaCuC}$, and $\mathrm{CuCiC}$ verbs, as well as derived verbs that may have the $\mathrm{CaCiC}$ sequence. The development presented by Sïbawayh and al-Farrā? clearly represents a regular sound law that can be formally represented as follows: ${ }^{*} i$, * $u>\varnothing / \mathrm{Cv}$.C_. I will discuss the four categories listed by al-Farrā? and Sībawayh separately.

11 The editor changed this to $a$-rahm, but in a footnote he points out the manuscript said ar-rihm, which is clearly the intended form here. 


\subsubsection{Syncope in the Verbs}

Sībawayh (IV, 113) shows that among the dialects that undergo this syncope, it regularly applies in the verb. As examples he cites forms like karuma $\rightarrow$ karma 'he is noble', Salima $\rightarrow$ Salma 'he knew', fușida $\rightarrow$ fuṣda 'he was bled' and Suṣira $\rightarrow$ Sușra 'it was squeezed'.

$\mathrm{He}$ also reports some cases where the $\mathrm{CvCu} / \mathrm{iC}$ sequence is not followed by a short vowel, and adding an epenthetic vowel to aid word-final CC cluster or CCC cluster that is created. Thus, he lists forms like lam yalid-hü $\rightarrow$ lam yald-hu $\rightarrow$ lam yalda-hū 'he begot him' and ințaliq $\rightarrow$ ințalq $\rightarrow$ ințalqa 'be free!'. Whether these reports should be understood as exceptional cases, or that the sound law described here is actually independent of the second vowel being in an open syllable, is not entirely clear.

In the following chapter, Sibawayh (IV, 116) points out that CaGiCa verbs that underwent vowel harmony to CiGiCa are also typical of the dialect of the Tamim (see $§$ 2.2.3 above for a discussion). These too undergo syncope, but only after the vowel harmony. Thus, one gets forms like šahida $\rightarrow$ šihida $\rightarrow$ šihda 'he witnessed', laSiba $\rightarrow$ liSiba $\rightarrow$ liSba 'he played', naSima $\rightarrow$ niSima $\rightarrow$ niSma 'he is glad' and ba?isa $\rightarrow$ birisa $\rightarrow$ bi?sa he is miserable'.

Al-Farrā? discusses this development in a less systematic way, but discussions of it can be found throughout Luġāt al-Quriān. He reports that Rabīiah and Tamìm drop the $i$ in fusila passives, citing Sufya and qudya 'it is settled' as examples (al-Farrā? Lugāat, 41). The Hijazi form ḥasuna 'he is nice, good' is hasna among the Tamīm (al-Farrā? Luġāt, 56). The broader application of this syncope, even affecting words other than $\mathrm{CaCuC}, \mathrm{CaCiC}$ and $\mathrm{CuCiC}$ stems is made clear by the fact that al-Farrā? (Lug்āt, 38) mentions that some of the Tamìm say yağdu 'he finds' and lam ?ağdi/a 'I didn't find' for yaǧidu and lam Pağid.

These forms discussed by Sìbawayh are the result of regular sound laws that allow us to develop a relative chronology of the developments of the vowel harmony followed by the syncope. As with other cases of variation described by the Grammarians, the unsyncopated forms are not presented as 'better' or standard. Rather, both forms are considered part of the Sarabiyyah. In Classical Arabic syncopated forms do not usually occur, the only place where they occur is when the verbs na fima 'he is glad' and ba?isa 'he is miserable' are employed as pseudo-verbs of emphatic qualification, such as nifma r-raǧulu 'what a wonderful man!' and bi?sa n-nisā?u 'what evil women!' (Fischer 2002, § 259-263). This lexical exception of these two verbs is typical of Classical Arabic but is not described by Sībawayh or al-Farrā? for the Sarabiyyah. 


\subsubsection{Syncope in Nouns}

While al-Farrā? does not refer explicitly to the application of this syncope in the context of verbs, he and Sībawayh both mention its application in nouns. It affects such words as faxid $\rightarrow$ fax $\underline{d}$ 'thigh',' 12 kabid $\rightarrow$ kabd 'liver', Sadud $\rightarrow$ fadd 'upper arm', rağul $\rightarrow$ rağl 'man'. When the vowel in the first syllable is a high vowel, we see the same development. Thus qudus $\rightarrow$ quds 'holiness' (alFarrā?, Lug்āt, 44) and huzu? $\rightarrow$ huz? 'mockery' (al-Farrā?, Luġāt, 26), funuq $\rightarrow$ Sunq 'neck' at-țunb $\rightarrow$ at-țunb 'tent rope' and Pibil $\rightarrow$ Pibl 'camels'. Even $\mathrm{CuCuC}$ plural formations are affected, and thus we see ar-rusul $\rightarrow$ ar-rusl 'prophets', humur $\rightarrow$ humr 'donkeys', xumur $\rightarrow$ xumr 'veils', ?uzur $\rightarrow$ ?uzr 'wraps' and furuš $\rightarrow$ furš 'pillows' (Sībawayh, III, 6o1). Derived nouns that have the expected environment undergo this development according to Sībawayh (although al-Farrā? never cites cases of such forms). Thus Sîbawayh (IV, 115) cites muntafixan > muntafxan 'swollen'.

For simple noun stems in Classical Arabic, syncopated forms are still quite frequent but always exist side-by-side with unsyncopated byforms: thus one finds mention in lexicons and grammars of forms like kabd besides kabid, Sunq beside Sunuq and Pibl besides Pibil, and even for plural forms mention is made of kutb besides kutub (e.g. Fischer 2002, § 88.2). However, these byforms are presented as fully lexicalized and optional in the language. The regular application of syncope is no longer recognized and forms like muntafxan < muntafixan do not seem to occur.

\subsubsection{Pronouns}

The pronouns huwa and hiya do not normally undergo syncope as they stand at the beginning of a word, but when preceded by $w a-, f a-$ or $l a-$, the phonetic environment is created where it would syncopate in the dialects of Najd, thus you get wa-hwa, fa-hya and la-hya. Al-Farrā? explicitly connects this practice to the Najdi dialects, whereas Sībawayh (IV, 151) is a bit more circumspect, and says: "the $h \bar{a}$ ? is quiesced when a $w \bar{a} w$, or fā? or lām stands before it, and that is your speech:wa-hwa dāhib, wa-lahwa xayrun mink, fa-hwa qā?im. And it is like that for hiya [...], so they drop the vowel like they drop it in faxidin $\rightarrow$ faxdin [etc.]" ${ }^{13}$ Those that drop the vowel in faxid $\rightarrow$ fax $\underline{d}$ as we saw in section $\S$ 2.2.4.2 are the people of Najd.

12 One would expect fix $\underline{d}$ here for dialects that have the Najdi vowel harmony. It seems that the syncope affected more dialects than those that underwent the vowel harmony.

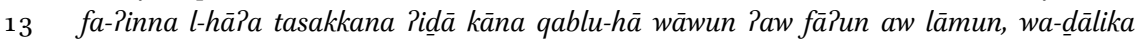
qawlu-ka: wa-hwa dِāhibun, wa la-hwa xayrun minka, fa-hwa qāPimun. Wa-kadālika hiya,

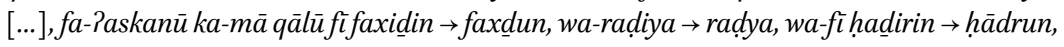
wa-saruwa $\rightarrow$ sarwa. 
In Classical Arabic the normal forms are huwa and hiya, although Fischer $(2002, \S 264.3)$ still makes note of the possibility to syncopate after $w a$ - and $f a$ as an option. For the grammarians we discussed here, it is not presented as a free option. Instead, it is clearly presented as the outcome of a regular development that takes place among eastern dialects; and it is not expected to see forms like wa-hwa in forms of Classical Arabic that do not also have kutb 'books' and Salma 'he knows'.

\subsubsection{4 $\mathrm{Li}-+$ Apocopate for Commands}

Another connection with the syncope that both Sïbawayh (IV, 151f.) and alFarrā? (Lug āt 29) provide is the treatment of the li- of command (lāmal-?amr). When this form is combined with an apocopate, it represents a command, for example li-ya?ti 'let him come!' li-na?xud 'let us take!' (Fischer 2002, §195). This li- of command can be preceded by $w a$ - 'and' and $f a$ - 'so'. As was the case with wa-huwa and fa-hiya, the $i$ of $l i$ - now stands in the phonetic environment that would undergo syncope in the Najdi dialects, both grammarians, comparing it with the other forms of syncope discussed so far, say that it is possible to elide this vowel, thus yielding forms like fa-l-yanzur 'so let him see!' and wa-l-yadrib 'and let him hit!' However, Sibawayh explicitly states that whoever leaves the vowel in hiya and huwa untouched also leaves the vowel in li- untouched. In other words, he explicitly describes the forms fa-li-yanzur and wa-li-yadrib for those that do not apply syncope.

This is rather different from the situation that we find in Classical Arabic. Where most of the cases described above, the standard prefers the unsyncopated forms, in this case the syncopation is obligatory, whereas forms like $\mathrm{fa}$-liyanzur, as explicitly endorsed by Sỉbawayh in non-syncopating dialects, is not considered part of the Classical Arabic language (Fischer 2002, § 195.1).

\subsubsection{Conclusions on the Syncope}

As should be clear from the above discussion, both Sībawayh and al-Farrā? make clear and consistent references to the existence of a syncopation rule of the high vowels $i$ and $u$ in the Sarabiyyah of Najd, this rule can be formulated formally as ${ }^{*} i, * u>\varnothing / C v$. C_. The varieties that have this form are by no means considered a 'deviation' from the norm, they are part of the normative construct of the Sarabiyyah that both authors seek to describe.

While in the varieties described by these grammarians the sound law simply applies regularly in those dialects that undergo it, surprisingly in the later Classical Arabic standard, the situation is very mixed. $\mathrm{CvCi} / \mathrm{uC}$ nominal stems, both as singulars and plurals, make it into this emergent norm in syncopated and unsyncopated forms, although the lack of syncopation seems to be pre- 
ferred. For verbs, this allowance of syncopation is unheard of except for the verbs na Sima and ba?isa where the syncopated forms, having undergone vowel harmony as well, nifma and bi?sa, and have become specialized as particles of emphatic qualification. For the pronouns both forms are possible, but the unsyncopated form dominates. Finally, for the li- of command, only the syncopated form wins out. It should be clear from these many differences that the Sarabiyya $h$ that these early grammarians describe is significantly different from the standard language that eventually becomes dominant.

\subsubsection{Barth-Ginsberg Alternation in the Prefix Vowel}

The Barth-Ginsberg alternation, first identified as a morphological pattern found in Hebrew and Aramaic, states that stative verbs in the prefix-conjugation that have a root vowel $a$ will have a prefix vowel $i$, whereas those that have a root vowel $u$ or $i$ will have a prefix vowel $a$. Thus, yiCCaC versus yaC$\mathrm{CiC}$ and yaCCuC. Bloch (1967) convincingly shows that this Barth-Ginsberg alternation was not just a development found in Hebrew and Aramaic, but also a pattern that Sỉbawayh — and with him many other Arab grammariansdescribes for the Sarabiyyah. Since Bloch's revolutionary article, it has become clear that the same alternation is found not only in Classical Arabic, but also in several modern dialects (Najdi Arabic, Ingham (1994, 23f.); and traces in, for example, Maltese, see Van Putten (2O2Oc)) and pre-Islamic Arabic (AlJallad and al-Manaser 2015). It is therefore beyond doubt that this alternation should be reconstructed for Proto-Arabic, and subsequently must be part of the shared ancestor of Hebrew, Aramaic and Arabic, that is—at the latest—central Semitic. ${ }^{14}$

Sïbawayh (IV, 110-113) considers the use of the Barth-Ginsberg alternation typical for all Arabs except those of the Hijaz. Thus, one says ?iSlamu 'I know' but ?aktubu 'I write' and ?adribu 'I hit'. This high vowel prefix occurs with every person prefix except the $y a$ - used for the 3 sg.m., and the 3 rd person plural/dual forms. ${ }^{15}$ Bloch $(1967,24)$ suggests that this is the result of an Arabic-internal dissimilation of the sequence " $y i->y a$ - Further evidence that the inclusion of the $y i$ - form is the original situation is found in the fact that certain words where the $y i$ shifted to $y \bar{\imath}$ the dissimilation was avoided, and we simply find

14 Kossmann \& Suchard (2018) make a compelling case that the Barth-Ginsberg alternation may even go as far back as the shared ancestor of Berber and Semitic.

15 This is different from the way it behaves in present-day Najdi Arabic which has invariable 1sg. ?a- but variable 3sg.m. ya-/yi- (Ingham 1994, 24f.). Hebrew, Aramaic, nor pre-Islamic Arabic (Al-Jallad and al-Manaser 2015) seem to have the exception of the 3sg.m. form as found in the Sarabiyyah. 
those original, such as in yiğalu 'he fears' rather than yawğalu and presumably also $y i i b \bar{a}$ which should likely be understood as a classicized version of a hamzahless form of the verb $y \bar{\imath} b \bar{a}$ that likewise had the $y \bar{\imath}$ sequence blocking the dissimilation.

Derived verbs that have a prefix with - $a$ - in textbook Classical Arabic, such as N-stem yanfaSilu, Gt-stem yafta Silu, tD-stem yatafaৎ̧alu, tL-stem yatafā $a$ alu and Ct-stem yastafৎilu are all likewise reported to have the $i$-prefixes for these dialects.

Al-Farrā? (Luġāt, 6-9) reports many of the same facts, but with more specific attribution: Qurayš and Kinānah always have $a$-vowel in derived stems (N, Gt, tD, tL, Ct), e.g. nasta Yinu; whereas Tamīm, Pasad and RabīYah say nistaรīnu,

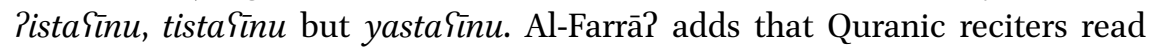
nista९̄nu but also in $\mathrm{G}(\mathrm{i} / \mathrm{a})$-stems such as tirkanū, tišärūna, tixäfüna, tìmannā [for ta?man ${ }^{w} n \bar{a}$ ], PiShad, Pïdan, tiswadd and titma?inna and other forms that are like it.

Afterwards, referring to these Barth-Ginsberg forms, al-Farrā? says "I followed in this manner, but the recitation follows the first (Hijazi) linguistic practice" (?ağraytu-hū Salā hā confirms that such forms described by Sībawayh and al-Farrā? are not just deviations from some unspoken norm, but can even be part of the self-reported speech of said grammarian.

Al-Farrā? continues to describe the rules in much the same way as Sībawayh and tells us that for G-stems the prefix is $2 i-, t i-, n i$ - but $y a$ - only in the fasila/yafialu. He explicitly adds that it is a mistake to say **tišrufu and **idribu, a practice widespread in modern dialects. ${ }^{17}$ For verbs that are fafalal yafialu, and thus are not stative verbs, one does not say **tidhabu etc. but simply tadhab, because the base verb is not a fasila verb. Al-Farrā? adds that al-Kisā?ī heard some of the Dubayr and ?asad use $i$ vowels there.

Neither Sïbawayh nor al-Farrā? specifically endorse the Hijazi absence of the Barth-Ginsberg alternation as being the proper form of the farabiyyah. In Classical Arabic, however, the Hijazi form without the Barth-Ginsberg alternation has become the only acceptable pronunciation (Fischer 2002, § 211.2; § 241.3).

16 Just before this section al-Farrā? explicitly cites "the reciters" as using Barth-Ginsberg alternation, so when he speaks of "the recitation", he is either making an explicit statement that those readers are wrong, or he is purely referring to the recitation he learned, which would have probably been from his teacher al-Kisā?ì, who indeed recites without Barth-Ginsberg alternation.

17 This statement should probably be understood as indicating that this practice was already becoming commonplace but was considered normatively unacceptable. 
Classical Arabic is often said to have one petrified form with Barth-Ginsberg alternation left, that is, ?ixālu 'methinks' (Bloch 1967, 27; Fischer 2002, § 244.3; Huehnergard 2017, 16). Indeed, Lisān al-Sarab (1304c) considers Pixālu, rather than ?axālu the most eloquent, whereas the latter is analogous. Such a normative preference however does not appear at all with the early grammarians. In fact, neither Sībawayh nor al-Farrā? mentions this form at all in their discussion of the alternation. ${ }^{18}$

\subsubsection{The Deictic Pronominal System}

Sïbawayh (II, 5, 77f.; IV, 182, 411) only has a few very short discussions on the deictic pronominal system. Al-Farrā? describes the system in more detail (Luġāt, 11, 12, 22, 94; MaSānī, I, 109). Principally he identifies a Hijaz versus Najd split, mentioning several forms that explicitly different between the two regions, the differences have been summarized in the table below. Not every form of the paradigm is mentioned explicitly, or assigned to one of the dialect groups explicitly, I have taken the liberty to fill in these forms as seems most likely, and placed them in square brackets.

Hijaz

Najd (Tamīm, Rasad, Qays, RabīYah)

Proximal

Distal

Proximal

Distal

\begin{tabular}{|c|c|c|c|}
\hline$[h \bar{a} \underline{d} \bar{a}], h a \bar{d} \mathbf{d} i h \bar{\imath}$ & $\underline{d a}$ àika, tilka & {$[h \bar{a} \underline{d} \bar{a}], h \bar{a} \underline{d} \bar{\iota}^{19}$} & $\underline{d} \bar{a} k a, t \bar{k} k a$ \\
\hline [hādāani, hātāni] & $\underline{d a} \bar{a} n i k a,[$ tānika $]$ & [hād̄ānni, hātānni] & dānnika, ${ }^{20}[$ tānnika $]$ \\
\hline hāPulā?i & PulāPika & (hā)Pulā & Pulāka \\
\hline
\end{tabular}

While the Najdi forms are reported for the Sarabiyyah, it is the Hijazi forms that see the most use in Classical Arabic prose. The Najdi $\underline{d} \bar{a} k a$ occurs occasionally in Classical Arabic prose besides $\underline{d} \bar{a} l i k a$, while $h \bar{a} \underline{d} \bar{i}, \hat{\imath} u \bar{a}(k a)$ and $\underline{d} \bar{a} k a$ are only on occasion used in poetry.

18 Sỉbawayh does mention the first-person plural form nixălu, the fact that he makes no special mention of the 1sg. form suggests it had no special position in his estimation.

19 Hädih in pause.

20 Al-Farrā?'s report that $\underline{d} \bar{a} n n i k a$ belongs to the dialects that say $\underline{d} \bar{a} k a$ disagrees with alMubarrad's report, who says that whoever says deallika also says d̄ānnika (III, 275). 


\subsubsection{Two Subsequent Hamzahs within a Single Word}

Sībawayh (III, $543 \mathrm{ff}$.) describes the dropping of the hamzah in words like ra?s

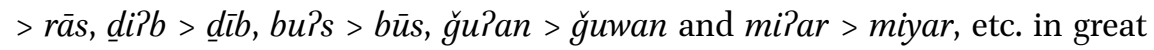
detail, and he does not express any negative (or positive) opinion. It is simply an option when speaking the Sarabiyyah. In the norms as presented in our textbooks today, such forms are not recognized as being part of Classical Arabic at all (Fischer $(2002, \S 42, \S 43)$, although Wright $(1896, \S 42)$ indeed describes the option neutrally).

To Sibawayh (III, 552), however, there is one environment in which the dropping of the hamzah is obligatory, namely, when two hamzahs follow one

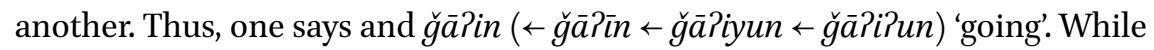
not mentioned explicitly, logically this also affects the verbs ?a?kulu $\rightarrow$ ?ākulu and ?u?allifu $\rightarrow$ ?uwallifu and the plural of ?imām, i.e. Pa.immah (for ?a?immah). In Classical Arabic the development of ?a?kulu $\rightarrow$ ?ākulu is considered regular (Fischer 2002, §40), whereas other cases are considered to take place only in nouns (Fischer 2002, §41a) but is said not to occur in the I-? verbs (Fischer 2002, § 41a.1). Sībawayh makes no such distinction between nouns and verbs, and instead presents it as a rule without exception. Al-Farrā? does not discuss these cases.

\subsection{Where is Classical Arabic?}

From the discussion in the previous section $(\S 2.2)$, we have seen that the early grammarians did not establish a single norm as to what the farabiyyah is. Instead, they admit a wealth of possibilities, occasionally provided with tribal attribution of certain features, but especially Sībawayh very often simply lists the options without specification. The collection and descriptions of free variation in the Sarabiyyah is a feature typical of the Arab grammarians - it seems to have been part of the very endeavour of being a grammarian. Even if we turn our attention to a grammarian as late as al-Zamaxšarì (d. 538/1144) in his al-Mufașșal fi al-Naḥw, we barely see any convergence towards a normative standard in his description. In the chapter on Pimālah, for example, he still describes all the cases of phonemic $\bar{e}$ found with Sïbawayh, even closely following his description (al-Zamaxšarī mufașsal, 158-16o). Even so, judging from vocalized Classical Arabic manuscripts that predate him, it seems quite clear that what eventually become the prescriptive norms of Classical Arabic had by his time been firmly established.

Rabin $(1951,13)$ explicitly sees much of the variation discussed above as deviations from the standard: "[The Arab grammarians] never considered the 
dialects as a form of speech in their own right, but as a collection of curious deviations from the literary language. All their data are measured on Classical Arabic." This, however, reveals more about Rabin's preconceived assumptions about the goals of the grammarians and the homogeneity of Classical Arabic, than it tells us about how the Arab grammarians discussed the possible linguistic variation within the Sarabiyyah. While it is certainly true that the grammarians did not consider the dialects as forms of speech in their own right, it is not true that they are presented as curious deviations from the literary language. All of the variations they described is what they considered to be the literary language. They do not describe them as deviations, but rather as an integral part of the norm.

For example, as we have seen above, both Sībawayh and al-Farrā? affirm that eastern dialects tend to drop $i$ and $u$ in $\mathrm{CvCi} / \mathrm{u}$ sequences. Never do we find statements of the kind "the people of the Hijaz say katif, and the people of Najd say katf, and the Sarabiyyah is katif." The description of the Hijazi and Najdi forms is the Sarabiyyah these grammarians seek to describe. This is often explicit in Sïbawayh's writing; when he lists a set of options, he ends such a discussion with a statement that all such options are farabiyy. Even when he explicitly calls one better (?ahsan, ?ağwad), he will often end such a discussion with a statement that the dispreferred form is Arabic too. We saw this in Sïbawayh's discussion of the long $-h \bar{u}$ and $-h \bar{\imath}$ after long vowels and diphthongs. While he considers the short forms better, "the full pronunciation is Sarabiyy." At no point is a contrast made between the variation he describes and what the Sarabiyyah is supposed to be.

This necessarily leads us to perhaps an unintuitive conclusion to the modern reader: If one were to read the whole of Sībawayh's Kitāb, one would not learn how to speak a single "Classical Arabic". Instead, one would have access to an astounding amount of - often mutually exclusive - variants. In fact, if one takes the statements of Sïbawayh seriously, we would find that the forms considered part of the standard language today could simply not exist at all. As an example, in Classical Arabic one would say taštahi-hi 'she desires it'. However, in section $\S 2.2 .1$ we learned that harmonized - $h i$ is proper to the dialects of Najd, while in the Hijaz they would say $-h \bar{u}$ (or $-h u$ ), whereas in section $\S 2.2 .5$ we learned that only the people in the Hijaz have ta- as a prefix of Gt-stems while all other regions have $t i$ - Thus, one expects either taštahì-hù or tištahí$h i$; one cannot read the Arab grammarians and learn that the proper Classical Arabic form is taštahi-hi, as they at no point explicitly prescribe that.

Still, one might wonder whether the prose of the grammarians themselves would not give away what they considered to be 'the standard'. After all, no matter which modern text edition of Sībawayh's Kitāb one consults, these contain 
all the features of standard Classical Arabic that we know today. But in light of the dominant standard language ideologies present today, and indeed a homogeneous standard having been present for many centuries already, such text editions are of course, quite meaningless. Relentless classicization of orthography and linguistic features is rampant in modern text editing practices, as well as historical copying practices. We do not have an autograph of Sïbawayh's book, nor of al-Farrā?'s works. Copies that have come down to us post-date their lifetimes by centuries, and postdate the establishment of a fairly rigid classical norm by centuries as well. As such, we simply cannot assume that the copies or editions we have today are reliable reflections of the version of the Sarabiyyah they themselves adhered to. Without the strict rules of meter and rhyme, the Classicizing trends which are already strongly present in poetry (C. Rabin 1955, 21 ), would have been even stronger in prose. I would argue that careful reading of their works can at least lead to a plausible inference that the norms of al-Farrā? and Sībawayh may have used in their own prose would have differed from the modern Classical Standard, and also likely differed from one another.

Al-Farrā? explicitly endorses the option to make a phonemic distinction between $/ \overline{\mathrm{a}} /$ and $/ \overline{\mathrm{e}} /$ in final-weak stems, saying this is most common among the Arabs and the Qurrā? (see § 2.2.2.2). This distinction was made in Quranic recitation by his teacher al-Kisā?ī, al-Kisā?î̀'s teacher Hamzah, and the teacher of Ḥamzah, al-Paimaš (see § 3.3.3.3). This phonemic distinction appears to have been a venerable Kufan tradition. I see no a priori reason to assume that this systematic phonemic distinction was only adhered to by these Kufan philologers in Quranic recitation. Al-Farrā?'s wording does not seem to imply that. Similarly, I see no reason to assume that the lack of harmony of -hum when preceding Palif al-wașl in, e.g. Salayhumu l-qawl can transparently be understood as a practice exclusive to Quranic recitation. Al-Farrā? explicitly calls this practice 'the most eloquent of linguistic practices' (?afșah al-lug $\bar{a} t$ ), and something that 'al-Kisā?ī used to adopt' (see § 2.2.1). And indeed, it is also something other Kufans like Ḥamzah and al-Pa@maš adopted, at least in recitation (see § 3.3.1).

Neither of these features is explicitly endorsed by Sībawayh, and from what we know of the recitation of the Basran readers, it appears to have rather been typical (at least in Quranic recitation) not to distinguish between $/ \bar{a} /$ and $/ \overline{\mathrm{e}} /$ and say Salayhimi l-qawl with harmony of both the internal vowel and the connecting vowel (van Putten and Sidky forthcoming). Sïbawayh seems to take the 'base' of the harmonized plural pronouns to be \{alayhimi, which could be carefully taken as a possible indication that he would have indeed preferred the Salayhimi l-qawl form. In light of these differences in description between Sībawayh and al-Farrā? which appear to align with regional practices of Quranic recitation, it seems to me likely that these two grammarians would have dif- 
fered in these features from one another in neutral prose, while both recognizing each other's options as part of the Sarabiyyah. Whatever the case, it is certainly unwarranted to assume that these two early grammarians would have agreed on a single standard Classical Arabic norm - which they both neglected to describe at all - when speaking and writing prose which just so happens to agree exactly with the modern norms, while it explicitly differed on these points compared to the strongly regional patterns in recitation. ${ }^{21}$

Despite the absence of an explicit normative position from the early grammarians, whenever modern scholarship speaks about the history of Arabic, including the language of the Quran, the assumption that the standard and uniform Classical Arabic was established by the grammarians-and understood by all from the very beginning of the grammarian endeavour to have the limited subset of grammatical features-permeates all argumentation and leads to conclusions that simply do not follow from the data. For example, Rabin adduces that "the dialect of the Quraish must have been more unlike the Classical than the present-day colloquials [...]. Had the Koran been composed in either the dialect of Quraish or in a "vulgar tongue", no amount of revision without altering the consonantal outlines could have made it as similar to Classical as it is." (Rabin 1955, 26). Rabin assumed here that the Arab grammarians had a clearly defined category of Sarabiyyah versus the dialect of Qurayš, but this is not at all what the grammarians present: The dialect of the Qurays is the Sarabiyyah, as are the dialects of Najd. There is no description of Classical Arabic in opposition to the descriptions of the dialects.

Despite the lack of a unified standard, modern Arabists consistently project this homogeneous standard of Classical Arabic back to the period of the early Grammarians or even earlier. For example, Blau \& Hopkins (1987, § 25.1) argue that case must be absent in construct in the Judeo-Arabic papyri they study because the 3rd plural masculine is הום־/-hum/, even in genitival position,

21 While the editing process and classicization certainly got rid of many of the more exotic and pre-Classical linguistic features of the Sarabiyyah in the writings of these early grammarians, occasionally traces of it appear to make it into the modern editions of the text. For example, the short form of the apocopate of kāna as yaku, taku etc. rather than yakun and takun is generally considered to be a typical feature of Quranic Arabic and poetry, but atypical of the standard Classical Arabic prose that these grammarians are often assumed to implicitly adhere to. Yet, al-Farrā? on multiple occasions in his Ma āan̄i in fact uses such short forms in his own prose, and not in order to highlight this feature of Quranic Arabic or the Sarabiyyah, e.g. fa-Pin yaku ka-d̄ālika fa-yanbaġi ?an yakūna hiț̣atan manșūbatan fi l-qirā?ah "so if it is like that, then it should be recited as hițtatan in the accusative" (alFarrā? Måān̄̄ I, 38) and fa-Pin yaku muwāfiqan li-t-tafsìri fa-huwa șawāb "so if this is in agreement with the explanation, then it is correct" (al-Farrā? Ma९ānī I, 94). 
where they say "according to Classical Arabic they should have contained $i . "$ The papyri they study were written around the same time that Sỉbawayh and al-Farrā? are active as grammarians, and both grammarians find the unharmonized forms of the pronoun completely acceptable. Thus, saying that the form with vowel harmony is the only option Classical Arabic "should" have, is anachronistic. It assumes a linguistic unity of Classical Arabic that is not shown to have existed and certainly is not presented as such by the early Arab grammarians.

Hopkins $\left(2020,72^{*}\right)$ claims that "in Classical Arabic (CA), the final vowel $\bar{a}$ is sometimes written with alif and sometimes written with $y \bar{a}^{2}$. According to early grammarians, Quranic tajwid and traditional pronunciation of $\mathrm{CA}$, the two spellings are in sound identical". But early grammarians in fact describe them as having different sounds (see § 2.2.2.2), and even much later grammarians like al-Zamaxšani express no normative opinion that Hopkins ascribes to the early grammarians. ${ }^{22}$

Another example is found in Blau $(1967, \S 4.1)$ who interprets سُلن "we were asked" as a shift of $i>u$, apparently taking the hollow root passive silna as the Classical Arabic form, although, according to the early grammarians, for hollow roots both $C \ddot{u} C n \bar{a}$ and $C u C n a \bar{a}$ are admitted besides silna (see $\S$ 2.2.2.5).

Blau $(1967, \S 8.3)$ likewise seems convinced that the li- of command always has to syncopate when $f a$ - precedes, when he says "the copyist (or the author), ... perhaps wrongly pronounced fali [instead of fa-l-, MvP]." However, fa-liyaktub rather than the now standard fa-l-yaktub was by no means considered wrong by the early grammarians (see $\S$ 2.2.4.4 and also $\S 3 \cdot 3 \cdot 2.2$ ).

However, it is not just those working on Middle Arabic that anachronistically project back later linguistic norms to the early Islamic period. Also, historical linguistic work on modern dialects often takes the Classical Arabic standard as the norm, subsequently misinterpreting archaisms in the dialects as innovations. An example of this is Blanc $(1964,44)$ who describes the retention of III- $y$ Pimālah in Christian and Jewish Baghdadi-like ?aSmi 'blind' < Paßmē, $k(a) s a \bar{a} l i$ $<$ kasālè 'lazy', bali 'yes' < balē and habbli 'pregnant' < ḥublē-as shifts from Old Arabic ${ }^{*} \bar{a}$ to $i$, rather than clear evidence that these dialects developed from varieties of Arabic that have a distinct phonemic $\bar{e}$ in this position rather than $\bar{a}$.

In order to understand the linguistic history of Arabic, the position of the Sarabiyyah within it and how we should understand the position of Middle

22 Incidentally, also the claim that the sounds are merged in tağwìd is incorrect. Four of the ten canonical readers keep them perfectly distinct, see $\S 3 \cdot 3 \cdot 3 \cdot 3$. 
Arabic and the modern dialects in relation to it, it is important not to essentialize the farabiyyah according to the rigid standard placed upon it today, but rather with the diversity which the Arab grammarians described it.

\subsection{Prescriptivism of the Grammarians}

The lack of explicit prescriptivism in the early grammatical tradition concerning a large amount of phonological, morphological and syntactic variation should not be understood as evidence that the data presented by the grammarians is an uncurated representation of the dialects of Arabic. In fact, if we compare what the grammarians describe to contemporary Arabic texts written in scripts other than Arabic, we find one very striking difference: The Arabic of this period, not filtered through the grammarian lens, lacks the full ?iSrāb and tanwin system which so quintessentially marks Classical Arabic and the Sarabiyyah. Some examples of such documents are the following:

(1) The Damascus Psalm fragment, written in Greek letters, datable to right around the active period of the earliest grammarians (end of the 8th, early 9 th century), seems to reflect a variety of Arabic that has mostly lost case, occasionally reflecting a genitive in construct before pronominal suffixes and using a marker - $\bar{a}$ for adverbials. See Al-Jallad (2O2Ob) for a discussion.

(2) The Arabic as reflected in Greek transcriptions of the 7th century has lost all word-final short vowels and tanwin, but retains evidence that $i a b \bar{u}$ 'father of' was still inflected for case (Al-Jallad 2017d). The pre-Islamic Graeco-Arabic material from the southern levant (around the 6th century) reflects a similar situation (Al-Jallad 2017a).

(3) The Judeo-Arabic papyri written in the early phonetic Judeo-Arabic spelling, a purely phonetic orthography that does not calque Arabic orthography, likely dated around the 8th or 9th century, show no sign of case inflection save for the inflection of the 'five nouns', which are found in the correct genitive forms in address lines (מין אכיח min Paxi-h 'from his

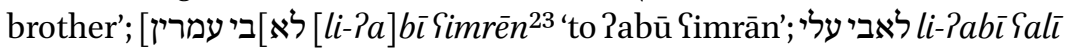
'to Pabū Yalī'; לאבי יעקוב li-Pabiya Yqūb 'to Pabū YaYqūb') (Blau and Hopkins 1987).

(4) The pre-Islamic Arabic written in the Safaitic script lacks tanwin and seems to have only retained the accusative $-a$ for both definite and indefinite nouns, while word-final $-u$ and $-i$ had been lost (Al-Jallad and al-

23 Note the $i$-umlaut Pimālah of a CiCCāC noun, as discussed above in section $§$ 2.2.2.1. 
Manaser 2015; Al-Jallad 2015, 69f.). The pre-Islamic Arabic written in Hismaic script may have had all the case vowels, but likewise lacked tanwin (Al-Jallad 2020a).

Indeed, regardless of the period from which an Arabic manual of grammar comes, one would hardly ever know that there was Arabic spoken at all without TiSrāb and tanwīn, ${ }^{24}$ if one would rely on just these grammars. In this sense the Arab grammarians are highly, but only implicitly, prescriptive; there was an essential part of Arabic variation and innovation present in what modern linguists would call "Arabic" that completely escapes any acknowledgement by the grammarians. Clearly to them any form of Arabic that did not have the full system of Pifrāb and tanwin was not considered proper "Arabic". This is also clear from the word used to denote these Arabic-defining final case vowels: Pi $i r a \bar{b}$, as a causative verbal noun of the root $\sqrt{ }$ irb, it is literally "the thing that makes something Arabic".

\subsection{Conclusion}

In this chapter we have examined several linguistic features described by the early Arab grammarians Sībawayh and al-Farrā?. From this discussion it is clear that these grammarians did not fix a prescribed homogeneous linguistic norm. Instead, we find that they described a large variety of different linguistic options, which are very often presented as equally valid without any normative opinion being expressed, far from establishing a rigid linguistic standard to which all speakers were expected to adhere. It, therefore, can hardly be said that "from its earliest times to the present, [Classical] Arabic has remained superficially almost unchanged" (Fischer 2002, 1). Instead, the Classical language as we know it today has become much less diverse than what the early Kufan and Basran grammarians allowed.

Whenever the grammarians do express a normative preference towards certain forms, they often take pains to point out that the other options are valid too, and when such a preference is expressed, this does not mean that the preferred option is the one that ends up in Classical Arabic. This we see for example in the case of having a fourth long vowel $\bar{e}$ as the reflex of ancient triphthongs written with the ?alif maqșürah, which al-Farrā? explicitly endorses, whereas in textbook Classical Arabic this phonemic distinction does not exist (§ 2.2.2.2).

24 Rare admissions are found in the early fourth Islamic century (see Versteegh 1995, 167, n. 11; Larcher 2018). 
Moreover, the features described by the grammarians often seem to represent clear, regular phonological developments in the varieties they describe, giving an impression that we are dealing with natural language that has undergone regular sound changes (especially Najdi vowel harmony and syncope, see $\S 2.2 .3$, § 2.2.4). However, in Classical Arabic as we know it today, the outcomes of these sound laws that still seemed regular at the time of the early grammarians have now lexicalized and grammaticalized in mixed forms. This is something we see for example with the syncopation of the $l i$ - before apocopates of command ( $\$$ 2.2.4.4), the use of the Barth-Ginsberg variant only for the fossilized form Pixālu 'methinks' (§2.2.5), and the lexically determined vowel harmony and syncope in ni\}ma and bi?sa (§ 2.2.4.1).

While there are clear prescriptive parameters within which the Sarabiyyah operates, it is clear that what they consider to be the Sarabiyyah was much broader than what becomes the Classical standard. It takes centuries before any kind of homogeneous standard comes forward from the grammarian enterprise. Suggesting that such a homogeneous grammatical standard was already recognized in the late 8th/early 9th century or even the pre-Islamic period is anachronistic. Moreover, as we will see in the next chapter, the linguistic variation described by the grammarians was not of mere theoretical interest but was actually liberally employed in the Quranic reading traditions.

The abundance of different options does not help us to achieve a clear answer as to what the language of the Quran is. Even if we accept the assertion of the Arab grammarians that the Quran it was revealed in the Sarabiyyah, that definition is clearly too broad to be meaningful, and we are left with the question: "which Sarabiyyah?" In the following chapters I will further explore this question. 